\title{
KEPEMIMPINAN KEPALA SEKOLAH DALAM MENINGKATKAN KINERJA GURU IPS DI SMP NEGERI 2 ARUNGKEKE, KABUPATEN JENEPONTO
}

\author{
${ }^{1 *}$ Sri Wahyuni, ${ }^{2}$ Kembong Daeng, ${ }^{3}$ Hasria Alang, ${ }^{4}$ Sulfaidah \\ ${ }^{1}$ SMP Negeri 2 Arungkeke, Jeneponto, Indonesia \\ ${ }^{2}$ Universitas Negeri Makassar \\ ${ }^{3}$ Pascasarjana STKIP Pembangunan Indonesia Makassar, Indonesia \\ ${ }^{4}$ Pendidikan Ekonomi STKIP Pembangunan Indonesia Makassar, Indonesia
}

*Email Korespondensi: wahyuniuni489@gmail.com

\section{INFO ARTIKEL}

Diterima 09 Juli 2021

Dipublikasikan 31 Juli 2021

\begin{abstract}
A B STRAK
Penelitian ini bertujuan untuk mendeskripsikan kinerja kepala sekolah, mendeskripsikan kinerja guru IPS, dan mendeskripsikan kepemimpinan kepala sekolah dalam meningkatkan kinerja guru IPS di SMP Negeri 2 Arungkeke, Kabupaten Jeneponto. Jenis penelitian yang digunakan yaitu penelitian gabungan, penelitian yang mengombinasikan atau mengasosiasikan bentuk kualitatif dan bentuk kuantitatif dalam satu penelitian. Sumber data kualitatif yang digunakan yaitu data wawancara informan dan data sekunder. Pengumpulan data melalui observasi, wawancara, dokumentasi, dan kajian pustaka, sedangkan model kuantitatifnya menggunakan angket atau kuesioer. Angket yang diberikan berisi daftar pernyataan yang dibuat secara berstruktur dengan bentuk tabel sesuai dengan indikator kepemimpinan kepala sekolah yang diterapkan. Hasil penelitian menunjukkan bahwa kinerja kepala sekolah SMP Negeri 2 Arungkeke, Kabupaten Jeneponto dapat meningkatkan pemahaman dan pengetahuan serta kinerja guru IPS sesuai dengan visi dan misi sekolah, kinerja guru IPS di SMP Negeri 2 Arungkeke diukur dalam proses pembelajaran, perencanaan program pembelajaran, pelaksanaan pembelajaran serta evaluasi pembelajaran sudah terlaksana dengan baik dan terstruktur, dan kepemimpinan kepala sekolah dalam meningkatakn kinerja guru IPS di SMP Negeri 2 Arungkeke, kabupaten jeneponto yaitu dengan memberikan motivasi semangat kerja guru, melakukan pembinaan disiplin, melakukan program kinerja guru, memberikan fasilitas belajar kepada guru IPS, memberikan penghargaan bagi guru yang berprestasi, memberikan insentif bagi guru.
\end{abstract}

Kata Kunci: Kepemimpinan Kepala Sekolah, Kinerja guru

\section{LEADERSHIP HEAD OF SCHOOL IN IMPROVING THE PERFORMANCE OF IPS TEACHERS IN SMP NEGERI 2 ARUNGKEKE, JENEPONTO REGENCY}

\begin{abstract}
This study aims to describe the performance of school principals, describe the performance of social studies teachers, and describe the principal's leadership in improving the performance of social studies teachers at SMP Negeri 2 Arungkeke, Jeneponto Regency. The type of research used is combined research, research that combines or associates qualitative and quantitative forms in one study. The sources of qualitative data used are informant
\end{abstract}


interview data and secondary data. Collecting data through observation, interviews, documentation, and literature review, while the quantitative model uses a questionnaire or questionnaire. The questionnaire given contains a list of statements made in a structured manner in the form of a table in accordance with the indicators of the principal's leadership applied. The results showed that the performance of the principal of SMP Negeri 2 Arungkeke, Jeneponto Regency could improve understanding and knowledge as well as the performance of social studies teachers in accordance with the school's vision and mission, the performance of social studies teachers at SMP Negeri 2 Arungkeke was measured in the learning process, planning learning programs, implementing learning and the evaluation of learning has been carried out well and structured, and the principal's leadership in improving the performance of social studies teachers at SMP Negeri 2 Arungkeke, Jeneponto district, namely by providing motivation for teacher work enthusiasm, conducting discipline development, conducting teacher performance programs, providing learning facilities for social studies teachers, provide awards for teachers who excel, provide incentives for teachers.

Keywords: Leadership head of school, Teacher Performance

\section{Pendahuluan}

Pendidikan merupakan kebutuhan dan tuntutan masyarakat yang diharapkan mampu mewujudkan masyarakat Indonesia seutuhnya dan berkualitas. Pendidikan secara formal diselenggarakan di sekolah demi memenuhi kebutuhan masyarakat. Ini berarti sekolah merupakan suatu organisasi untuk mewujudkan penyelenggaraan pendidikan. Penyelenggaraan pendidikan tersebut tentunya memerlukan pengelolaan untuk mencapai tujuan seperti yang diharapkan. Sebagaimana yang tertuang dalam Undang- Undang RI Nomor 2 tahun 1989 pasal 10 ayat (2) disebutkan bahwa sekolah sebagai wadah penyelenggaraan proses belajar mengajar, sehingga dapat dikatakan bahwa sekolah merupakan organisasi yang mempunyai kewenangan untuk menyelenggarakan proses belajar mengajar untuk mewujudkan tujuan pendidikan nasional.

Pendidikan formal sendiri adalah jalur pendidikan yang terstruktur dan berjenjang yang terdiri atas pendidikan dasar, pendidikan menengah, dan pendidikan tinggi. Pendidikan formal inilah yang lebih kita kenal sebagai lembaga pendidikan berupa sekolah di mana dalam pelaksanaannya dibutuhkan peran pemimpin yang baik.

Sukses tidaknya pendidikan dan pembelajaran di sekolah sangat dipengaruhi oleh kemampuan kepala sekolah dalam mengelola setiap komponen sekolah. Kemampuan kepala sekolah tersebut terutama berkaitan dengan pengetahuan dan pemahaman mereka terhadap manajemen dan kepemimpinan, serta tugas yang dibebankan kepadanya, karena tidak jarang kegagalan pendidikan dan pembelajaran di sekolah disebabkan oleh kurangnya pemahamankepala sekolah terhadap tugas-tugas yang harus dilaksanakannya.

Kepala sekolah sebagai pemimpin di sekolah merupakan bagian dari penggerak dalam kehidupan sekolah, untuk mencapai tujuan yang telah menjadi visinya tersebut ada 2 tugas penting, yaitu : 1) Kepala Sekolah berperan sebagai kekuatan sentral, 2) Kepala Sekolah harus memahami tugas dan fungsi (para tenaga pendidik) demi keberhasilan sekolah, serta memiliki kepedulian kepada staf dan siswa. Dengan demikian kepala sekolah merupakan pemimpin pendidikan tingkat satuan atau sekolah yang harus mampu bertanggung jawab terhadap perkembangan mutu pendidikan di sekolah yang dipimpinnya.

Kepala sekolah sebagai pemimpin pendidikan di suatu sekolah harus dapat mengenal dan mengerti berbagai kedudukan, keadaan dan apa yang menjadi kebutuhan para bawahannya (Tenaga Pendidik dan Kependidikan). Sehingga dalam proses kerja sama dapat berjalan dengan baik dalam upaya memperbaiki mutu sekolah serta mencapai tujuan bersama. Kegagalan dapat mencerminkan kurang berhasilnya perilaku serta peranan kepemimpinan seorang kepala sekolah, maka dari itu kepala sekolah harus mampu bertanggung jawab serta mengambil kebijakan dan keputusan yang baik untuk meningkatkan kualitas pendidikan di sekolah yang dipimpinnya.

Kepemimpinan pendidikan sangat berkaitan dengan masalah kepala sekolah dalam meningkatkan hubungan secara efektif dengan para pendidik dalam situasi yang kondusif. Di mana peran pendidik sangatlah penting untuk menghasilkan lulusan yang berkualitas dan berguna bagi masyarakat, bangsa, dan Negara. Guru adalah pendidik profesional dengan tugas utama mendidik, mengajar, membimbing, mengarahkan, melatih, menilai, dan mengevaluasi peserta didik pada jalur pendidikan formal, yaitu 
pendidikan dasar, dan pendidikan menengah. Proses pembelajaran dalam pendidikan mengedepankan konsep memanusiakan manusia atau lebih dikenal dengan sebutan teori humanistik. Teoribelajar humanistik ialah sesuatu teori dalam pembelajaran yang mengedepankan cara memanusiakan manusia, sehingga potensi dirinya dapat berkembang, aliranini memandang belajar sebagai proses untuk menemukan dirinya atau memanusiakan manusia dengan segala potensinya.

Untuk meningkatkan kinerja guru kepala sekolah harus mengetahui prinsip-prinsip tentang kinerja guru seperti memberdayakan tenaga kependidikan melalui kerja sama atau kooperatif dimaksudkan bahwa dalam peningkatan profesionalisme tenaga kependidikan di sekolah, kepala sekolah harus yang terkaitdalam melaksanakan setiap kegiatan, memberi kesempatan kepada para tenaga kependidikan untuk meningkatkan profesinya secara persuasif dan dari hati ke hati, mendorong keterlibatan seluruh tenaga kependidikan, dimaksudkan bahwa kepala sekolah harus berusaha untuk mendorong keterlibatan semua tenaga kependidikan dalam setiap kegiatan sekolah.

Berdasarkan konteks penelitian di atas, maka penulis menduga kepemimpinan kepala sekolah sangat berpengaruh terhadap kinerja guru. Olehnya itu, SMP Negeri 2 Arungkeke dipandang perlu untuk melakukan suatu penelitian secara mendalam guna memperoleh data yang benar dan akurat, sesuai dengan kondisidan kenyataan di lapangan, sehingga penelitian ini dapat dipertahankan agar mencapai hasil yang diharapkan sesuai dengan standar pendidikan Nasional. Tujuan penelitian ini adalah mendeskripsikan kinerja kepala sekolah dan guru IPS dan di SMP Negeri 2 Arungkeke, Kab. Jeneponto serta kepemimpinan kepala sekolah dalam meningkatkan kinerja guru IPS di SMP Negeri 2 Arungkeke, Kab. Jeneponto.

\section{Metode Penelitian}

Penelitian ini bersifat deskriptif, sehingga teknik penyajianya menggunakan studi deskriptif analitik, artinya menganalisis data apa adanya dengan dasar dari data kualitatif, yang diperkuat dengan berpikir induktif dan pemahaman teori, serta diperkuat dengan analisis data untuk menjelaskan fenomena dan aspek tertentu. Untuk memperoleh data dan informasi yang valid, penulis melaksanakan pengumpulan dengan teknik observasi adalah suatu proses pengamatan secara langsung terhadap objek penelitian. Objek penelitian yang dimaksud adalah kepemimpinan kepala sekolah dalam meningkatkan kinerja guru di SMP Negeri 2 Arungkeke, teknik wawancara dalam penelitian ini menggunakan teknik wawancara mendalam dan terbuka, yaitu proses wawancara yang dilakukan peneliti dengan mengajukan pertanyaan-pertanyaan yang tidak dibatasi jawabannya, artinya pertanyaan yang mengundang jawaban terbuka, dan teknik dokumentasi yaitu mengumpulkan data melalui peninggalan tertulis. Teknik ini sering disebut sebagai studi dokumenter yakni pengumpulan data dengan cara pengumpulan analisis terhadap dokumen-dokumen yang berisi data yang menunjang penelitian tentang kepemimpinan kepala sekolah dalam meningkatkan kinerja guru di SMP Negeri 2 Arungkeke.

\section{Hasil dan Pembahasan}

\subsection{Kinerja Kepala Sekolah SMP Negeri 2 Arungkeke}

Kinerja kepala sekolah merupakan kemampuan untuk melaksanakan pekerjaan atau tugas yang dimiliki dalam menyelesaikan suatu pekerjaan di sekolah yang dipimpinnya. Kinerja merupakan hasil kerja suatu organisasi dalam rangka mewujudkan tujuan strategik, kepuasan pelanggan dan kontribusinya terhadap lingkungan strategik. Menurut Bernadin, Kene, dan Johnson (1995) mendefinisikan kinerja sebagai outcome hasil kerja keras organisasi dalam mewujudkan tujuan strategik yang ditetapkan organisasi, kepuasan pelanggan serta kontribusinya terhadap perkembangan ekonomi masyarakat. Oleh karena itu, kinerja merupakan bentuk bangunan yang multi dimensional, sehingga cara mengukurnya sangat bervariasi tergantung kepada banyak faktor.

Kinerja kepala sekolah SMP Negeri 2 Arungkeke dalam rangka mempertahankan bahkan meningkatkan pemahaman dan pengetahuan guru sudah berjalan dengan sangat baik sesuai dengan visi dan misi sekolah. Kepemimpinan yang diterapkan oleh kepala sekolah sudah berjalan dengan baik, namun sarana dan prasarana sekolah perlu ditingkatkan karena terbatasnya alat teknologi seperti komputer dan print 
sehingga para guru kewalahan jika harus antri apabila akan menyelesaikan tugas administrasinya. Selain dari sarana dan prasarana, pembayaran insentif bagi guru dan pegawai honorer sudah berjalan sebagaimana juknis dan jumlah yang telah ditentukan. Kemudian pengelolaan dana operasional sekolah (BOS) lebih terorganisir dan transparan, kepemimpinan kepala sekolah yang diterapkan ini memicu meningkatnya jumlah siswa dari tahun 2019 hingga saat ini dan kesejahteraan guru pun terpenuhi.

\subsection{Kinerja Guru IPS SMP Negeri 2 Arungkeke}

Seiring dengan perkembangan zaman terkait generasi muda sebagai penerus masa depan, pada hakikatnya adalah sebagai tongkat stafet di zamannya, mereka perlu dibekali pendidikan yang baik dan berkualitas agar tidak menjadi objek belaka yang hanyut oleh derasnya pengaruh budaya yang mengarah pada destruktif. Mereka diharapkan mampu memberi warna di masa yang akan datang, olehnya itu sekolah merupakan salah satu tempat yang tepat untuk mempersiapkan bekal tersebut agar mampu mewujudkan generasi yang membanggakan.

Menurut Achmad S. Ruky, kinerja adalah pengalih bahasaan dari kata Inggris yaitu performance yang berarti prestasi, pertunjukan, dan pelaksanaan tugas (Ruky, 2002:14), sedangkan menurut Henry Bosleywoolf, performance berarti "the execution of an action". Berdasarkan dua pengertian di atas dapat dikatakan bahwa kinerja berarti tindakan menampilkan atau melaksanakan suatu kegiatan. Oleh karena itu kinerja sering juga diartikan sebagai penampilan kerja atau perilaku kerja. Banyak ahli telah memberikan definisi tentang kinerja, yaitu suatu kemampuan kerja atau prestasi kerja yang optimal. Dengan demikian istilah kinerja mempunyai pengertian akan adanya suatu tindakan atau kegiatan yang ditampilkan oleh seseorang dalam melaksanakan aktivitas tertentu.

Dari pembahasan tersebut maka dapat ditarik kesimpulan bahwa kinerja guru adalah suatu aktivitas guru yang dilakukan dalam rangka membimbing, mendidik, dan melakukan transfer knowledge kepada anak didik sesuai dengan kemampuan keprofesionalan yang dimilikinya dan hasil atau taraf kesuksesan yang dicapai seorang guru dalam bidang pekerjaannya menurut kriteria tertentu dan dievaluasi oleh pimpinan lembaga pendidikan terutama kepala sekolah. Seorang guru itu harus selalu memperhatikan aspek-aspek kinerjanya. Guru di sini dituntut untuk bisa menyusun rencana pembelajaran, melaksanakan pembelajaran, melaksanakan hubungan antar pribadi, melaksanakan penilaian hasil belajar, melaksanakan program pengayaan dan remedial.

Kinerja guru berkaitan dengan kemampuan guru dalam mengelola pembelajaran dan pengembangan siswa sebagai individu-individu yang mencakup pemahaman peserta didik, perencanaan, pelaksanaan maupun tahap evaluasi pembelajaran, dalam hal ini guru sebagai tenaga pendidik maupun ujung tombak yang menentukan berhasilnya proses pembelajaran di kelas. Oleh karena itu, kinerja guru dalam kegiatan pembelajaran harus dilaksanakan secara maksimal, maka dari itu dibutuhkan seorang tenaga pendidik yang berkompeten dan mampu menguasai materi dalam mengajar, metode pembelajaran kemudian mengevaluasi hal pengajaran yang telah diajarkan kepada peserta didik. Jadi sebagaimana yang telah dijelaskan di atas bahwa guru harus mampu memberikan kinerja yang berkompeten dan profesional di bidangnya khususnya guru Ilmu Pengetahuan Sosial.

Kinerja guru IPS dalam penelitian ini diukur dalam proses pembelajaran, perencanaan program pembelajaran, pelaksanaan pembelajaran serta evaluasi pembelajaran. Berikut ini penjelasan secara lengkap mengenai kinerja guru IPS di SMP Negeri 2 Arungkeke Kabupaten Jeneponto :

a. Perencanaan Program Kegiatan Pembelajaran

Perencanaan program kegiatan pembelajaran merupakan unsur yang sangat penting dalam proses pembelajaran karena merupakan bahan yang akan disampaikan kepada peserta didik saat proses pembelajaran berlangsung, sehingga guru memiliki pegangan dan tolak ukur di dalam proses pembelajaran, . perencanaan proses pembelajaran ini meliputi prota, prosem, silabus, dan RPP.

b. Pelaksanaan Kegiatan Pembelajaran

Hasil penelitian penulis di lapangan menunjukkan bahwa proses kegiatan pembelajaran di SMP Negeri 2 Arungkeke Kabupaten Jeneponto telah berjalan dengan baik, hal ini dapat dilihat pada keaktifan guru dan peserta didik dalam mengikuti kegiatan pembelajaran baik melalui kegiatan ekstrakurikuler maupun intrakurikuler sesuai jadwal yang telah ditentukan. 
Keberhasilan pembelajaran tidak hanya ditentukan oleh jumlah jam yang memadai, tetapi juga sangat ditentukan oleh kompetensi guru. Ada empat kompetensi yang harus dimiliki oleh seorang guru sehingga ia dapat menjalankan tugas mengajarnya secara profesional, yakni kompetensi profesional, kompetensi pedagogis, kompetensi sosial dan kompetensi personal atau kepribadian. Kompetensi profesional berkaitan dengan kemampuan dan penguasaan pendidik terhadap materi yang akan diajarkan, kompetensi pedagogis berkaitan dengan kemampuan dan keahlian pendidik dalam merencanakan, melaksanakan dan mengevaluasi pembelajaran. Kompetensi sosial berkaitan dengan kemampuan dan keterampilan sosial yang dimiliki oleh guru untuk membangun komunikasi baik terhadap peserta didik, teman sejawat dan orang tua peserta didik berkaitan dengan tugas-tugas mengajarnya. Kompetensi personal berkaitan dengan kemampuan dan kepribadian seorang pendidik sehingga ia dapat menjadi contoh dan model bagi pengembangan perilaku peserta didik.

Pelaksanaan kegiatan pembelajaran dalam hal ini guru bertugas dan bertanggung jawab secara optimal selama proses belajar mengajar berlangsung, yakni kegiatan pengolahan kelas, penggunaan media dan materi, penggunaan strategi dan metode pembelajaran. Proses pembelajaran tentunya seorang guru harus mampu memberikan motivasi kepada siswa agar siswa memiliki semangat belajar dan mampu menyerap apa yang disampaikan oleh gurunya.

c. Evaluasi / Penilaian Pembelajaran

Evaluasi atau penilaian pembelajaran adalah suatu kegiatan yang bertujuan untuk mengetahui tercapai atau tidaknya tujuan pembelajaran dan proses pembelajaran yang telah dilakukan. Pada tahap ini, seorang guru dituntut untuk memiliki kemampuan dalam menentukan pendekatan dan cara-cara evaluasi, penyusunan alat-alat evaluasi, pengolahan, dan penyusunan hasil evaluasi. Seorang pendidik dalam menyampaikan materi tentunya ada tolak ukur untuk mengetahui apakah materi yang disampaikan kepada peserta didik dapat diterima dengan baik atau tidak.

\subsection{Kepemimpinan Kepala Sekolah Dalam Meningkatkan Kinerja Guru IPS di SMP Negeri 2 Arungkeke} Kepemimpinan adalah jenis khusus hubungan kekuasaan yang ditentukan oleh anggapan para anggota kelompok bahwa seorang dari anggota kelompok itu memiliki kekuasaan untuk menentukan pola perilaku terkait dengan aktivitasnya sebagai anggota kelompok (Wibowo, 2011). Kepemimpinan merupakan seni dalam mengolah kemampuan dan keberanian mengatur dan mengambil keputusan (Sagala, 2018). Kepemimpinan sekolah menjadi sangat penting dalam rangka untuk memimpin dan menjalankan kehidupan sekolah. Dalam masa pandemi ini peran kepala sekolah menjadi sentral, karena kepala sekolah memiliki Kewenangan tertinggi dalam pelaksanaan dan pengambilan keputusan dalam sekolah.

Pendidikan profesional guru dapat memberikan kontribusi yang berpengaruh terhadap kegiatan pengajaran, dalam meningkatkan kinerja guru maka perlu adanya pengawasan dari pihak atasan. Pengawasan yang dilalukan oleh pihak pemimpin ini dimaksudkan untuk menjamin agar pelaksanaan program pengajaran yang dilakukan oleh guru sesuai dengan rencana, kebijakan, dan ketentuan-ketentuan yang telah ditetapkan. Tujuan dari pengawasan ditunjukkan untuk mewujudkan efisiensi, efektivitas ketentuan dan ketertiban pelaksanaan program pembelajaran.

Upaya yang dilakukan oleh kepala sekolah untuk meningkatkan kinerja guru IPS di SMP Negeri 2 Arungkeke dari tahun 2019 hingga 2020. Penilaian tersebut mencakup perencanaan dan pelaksanaan pembelajaran sampai dengan tahap evaluasi, kegiatan kolektif guru lewat MGMP, pengembangan modul pembelajaran, dan tugas sebagai pengawas ujian sekolah dan ujian nasional.

Peningkatan kinerja guru IPS SMP Negeri 2 Arungkeke dapat dilihat dari tabel perbandingan kinerja guru IPS yang peneliti analisis sesuai dengan temuan lapangan dan diperkuat oleh hasil wawancara dengan beberapa informan penelitian ketika melakukan observasi di lokasi, yakni SMP Negeri 2 Arungkeke berikut: 
Tabel I

Perbandingan Peningkatan Kinerja Guru IPS Kelas IXTahun 2019-2020 Menurut SKP Kepala Sekolah

\begin{tabular}{|c|c|c|c|c|}
\hline \multirow[b]{2}{*}{ NO. } & \multirow{2}{*}{$\begin{array}{l}\text { SKP GURU IPS } \\
\text { KELAS IX } \\
\text { TAHUN } 2019\end{array}$} & \multicolumn{3}{|c|}{ SKP GURU IPS } \\
\hline & & NILAI/PREDIKAT & $\begin{array}{c}\text { KELAS IX TAHUN } \\
2020\end{array}$ & NILAI/PREDIKAT \\
\hline 1. & $\begin{array}{c}\text { Orientasi } \\
\text { pelayanan }\end{array}$ & 91 (Sangat Baik) & $\begin{array}{l}\text { Orientasi } \\
\text { pelayanan }\end{array}$ & 98 (Sangat Baik) \\
\hline 2. & Integritas & 91 (Sangat Baik) & Integritas & 95 (Sangat Baik) \\
\hline 3. & Komitmen & 89 (Baik) & Komitmen & 92 (Sangat Baik) \\
\hline 4. & Disiplin & 91 (Baik) & Disiplin & 91 (Sangat Baik) \\
\hline 5. & Kerjasama & 90 (Baik) & Kerjasama & 91 Sangat (Baik) \\
\hline 6. & Kepemimpinan & - & Kepemimpinan & - \\
\hline & Jumlah & 452 (Baik) & & 457 (Sangat Baik) \\
\hline
\end{tabular}

Sumber : SKP Guru IPS Kelas IX Tahun 2019 dan 2020

Tabel II

Perbandingan Peningkatan Kinerja Guru IPS Kelas VII dan VIII Tahun 2019-2020

\begin{tabular}{|c|c|c|c|c|}
\hline \multirow[b]{2}{*}{ NO. } & SKP GURU IPS & \multicolumn{3}{|c|}{ SKP GURU IPS } \\
\hline & $\begin{array}{l}\text { KELAS VII/VIII } \\
\text { TAHUN } 2019\end{array}$ & NILAI/PREDIKAT & $\begin{array}{c}\text { KELAS IX TAHUN } \\
2020\end{array}$ & NILAI/PREDIKAT \\
\hline 1. & $\begin{array}{l}\text { Orientasi } \\
\text { pelayanan }\end{array}$ & 76 (Baik) & $\begin{array}{l}\text { Orientasi } \\
\text { pelayanan }\end{array}$ & 80 (Baik) \\
\hline 2. & Integritas & 76 (Baik) & Integritas & 81 (Baik) \\
\hline 3. & Komitmen & 77 (Baik) & Komitmen & 83 (Baik) \\
\hline 4. & Disiplin & 76 (Baik) & Disiplin & 80 (Baik) \\
\hline 5. & Kerjasama & 77 (Baik) & Kerjasama & 90 (Sangat Baik) \\
\hline 6. & Kepemimpinan & - & Kepemimpinan & - \\
\hline & JUMLAH & 385 (Baik) & & 414 (Baik) \\
\hline
\end{tabular}

Sumber : SKP Guru IPS Kelas VII dan VIII Tahun 2019 dan 2020

Tabel yang penulis tampilkan di atas merupakan hasil rekapitulasi perbandingan peningkatan kinerja guru IPS di SMP Negeri 2 Arungkeke pada tahun 2019-2020 sesuai dengan indikator kepemimpinan kepala sekolah dalam meningkatkan kinerja guru yang penulis tampilkan tabel kuesioner penelitian terkait indikator kepemimpinan kepala sekolah dalam meningkatkan kinerja guru IPS di SMP Negeri 2 Arungkeke:

Tabel III

Angket Penelitian Peningkatan Kinerja Guru IPS

\begin{tabular}{|c|c|c|c|c|}
\hline No. & $\begin{array}{l}\text { Indikator Kepemimpinan Kepala } \\
\text { Kekolah }\end{array}$ & Terlaksana & $\begin{array}{c}\text { Kurang } \\
\text { terlaksana }\end{array}$ & $\begin{array}{c}\text { Belum } \\
\text { terlaksana }\end{array}$ \\
\hline 1. & Memotovasi semangat kerja & $\checkmark$ & & \\
\hline 2. & Pembinaan disiplin & $\checkmark$ & & \\
\hline 3. & Membangun kerja aktif dan kreatif & $\checkmark$ & & \\
\hline 4. & Memberikan Fasilitas Belajar & $\checkmark$ & & \\
\hline 5. & Pemberian Insentif & $\checkmark$ & & \\
\hline 6. & Pemberian penghargaan & $\checkmark$ & & \\
\hline 7. & Melakukan kunjungan kelas & & $\checkmark$ & \\
\hline
\end{tabular}


Sesuai dengan cara peningkatan kinerja guru yang dipaparkan kepala sekolah dalam dalam indikator kepemimpinan kepala sekolah di SMP Negeri 2 Arungkeke, berikut merupakan hasil penelitian yang di lakukan peneliti di SMP Negeri 2 Arungkeke dalam hal peningkatan kinerja guru IPS menurut angket penelitian yang ditampilkan pada tabel tersebut, berikut beberapa poin yang diterapkan kepala sekolah dalam meningkatkan kinerja guru IPS di SMP Negeri 2 Arungkeke:

a. Memotivasi Semangat Kerja Guru

Motivasi merupakan salah satu faktor untuk menjadi daya dorong dalam melakukan sesuatu. Selain faktor kemampuan, motivasi juga dibutuhkan untuk meningkatkan kinerja seseorang. Secara umum sumber motivasi terbagi menjadi dua yaitu motivasi yang berasal dari dalam diri manusia (internal) yakni bagi diri pribadi seorang guru dan motivasi yang berasal dari luar diri manusia (eksternal) yakni dari lingkungan dalam hal ini pemimpin sekolah yang sangat berperan dalam memberikan motivasi kerja bagi gurunya.

Salah satu upaya kepemimpinan kepala sekolah dalam meningkatkan kinerja guru di SMP Negeri 2 Arungkeke, Kabupaten Jeneponto adalah dengan memberikan motivasi kerja kepada semua guru khususnya yang bertanggung jawab di mata pelajaran IPS, motivasi kerja yang dimaksud di sini adalah dengan memberikan contoh positif bagi guru sebab ketika pemimpin mencontohkan kerajinan maka semua bawahan akan menerapkan hal yang sama. Kemudian motivasi selanjutnya berupa penyampaian target yang akan dicapai agar para guru lebih fokus dengan kinerjanya untuk mencapai target yang telah diberikan oleh pemimpin, penghargaan bagi guru yang memiliki prestasi baik dalam bentuk lisan maupun bingkisan agar setiap karyanya bisa diapresiasi oleh kepala sekolah sehingga hal tersebut dapat meningkatkan semangat kerja dan kinerja guru.

b. Pembinaan Disiplin

Keberhasilan suatu lembaga pendidikan sangat ditentukan oleh kepala sekolah sebagai pemimpin tertinggi, karena kepala sekolah merupakan unsur terpenting dan berdampak langsung terhadap keberhasilan sekolah dan peningkatan kinerja bawahannya. Berdasarkan hasil penelitian yang penulis dapatkan di SMP Negeri 2 Arungkeke bahwa dalam meningkatkan kinerja guru IPS, kepala sekolah memberikan bimbingan kedisiplinan untuk menjamin kegiatan pendidikan secara efektif dan efisien.

Pembinaan tidak hanya dilihat dari bidang administrasi maupun organisasi saja, akan tetapi juga ditunjukkan dengan sikap mental guru yang merupakan sumber daya manusia paling utama dalam berlangsungnya proses belajar mengajar di kelas, dengan demikian akan tercipta tenaga pendidik yang bermental baik, berkualitas dan bertanggung jawab terhadap tugas yang diberikan. Dalam meningkatkan kinerja guru IPS di SMP Negeri 2 Arungkeke, kepala sekolah selalu menerapkan kedisiplinan waktu dan berpakaian. Kedisiplinan dalam jam kerja dalam hal ini mematuhi hari dan jam mengajar oleh guru berupa jam masuk hingga jam pulang sekolah.

Pembinaan kedisiplinan yang terapkan oleh kepala sekolah SMP negeri 2 Arungkeke bertujuan untuk mendidik guru agar lebih disiplin terutama pada waktu jam masuk dan pulang. kemudian kedisiplinan berpakaian sebagaimana dengan kebijakan sekolah yang harus dilakukan, yakni berpakaian khaki pada hari senin dan selasa, hitam putih pada hari Rabu, dan batik pada hari Jumat hingga Sabtu.

c. Melakukan Program Kinerja Guru

Kegiatan pelatihan bagi guru pada dasarnya merupakan suatu bagian yang integral dari manajemen dalam bidang ketenagaan di sekolah dan merupakan upaya untuk mengembangkan pengetahuan dan keterampilan guru sehingga diharapkan dapat memperoleh keunggulan kompetitif dan dapat memberikan pelayanan yang baik. Dalam meningkatkan kinerja guru tentunya ada solusi yang dilakukan salah satunya yaitu dengan mengadakan workshop (pelatihan) untuk guru khususnya yang bertanggung jawab di mata pelajaran IPS.

Salah satu hal yang menjadi kunci utama dalam peningkatan kinerja guru IPS terletak pada strategi kepemimpinan kepala sekolah yang bertanggung jawab atas penyelenggaraan kegiatan pendidikan, administrasi sekolah, pembinaan tenaga kependidikan, pendayagunaan dan pemeliharaan sarana dan prasarana sekolah. Tugas dan tanggung jawab yang harus diemban oleh kepala sekolah dalam memimpin atau mengelola administrasi sekolah yaitu meningkatkan mutu pendidikan, artinya bahwa seorang kepala 
sekolah dituntut untuk mampu mengelola seluruh sumber daya pendidikan yang ada di sekolah sehingga mampu mendukung dalam mewujudkan tujuan pendidikan yang akan dicapai.

d. Memberikan Fasilitas Belajar Pada Guru IPS

Belajar merupakan suatu proses tingkah laku individu melalui interaksi dengan lingkungan. Belajar memegang peranan penting dalam perkembangan kebiasaan, sikap, keyakinan, tujuan, kepribadian, dan bahkan persepsi manusia., dengan belajar manusia dapat mengembangkan potensi yang dibawanya sejak lahir. Pendidikan formal selalu diikuti pengukuran dan penilaian, demikian juga dalam proses belajar mengajar.

Pentingnya peranan pendidikan sebagai proses perkembangan kebiasaan, sikap, keyakinan, tujuan, kepribadian, dan bahkan persepsi manusia dengan demikian perlu di tunjang dengan fasilitas yang mendukung pembelajaran seperti papan tulis, LCD, dan alat pendukung lainnya.

e. Pemberian Penghargaan

Penghargaan (Reward) bagi guru adalah suatu bentuk penghargaan atau imbalan yang diberikan kepada seorang guru karena telah berperilaku baik, melakukan sesuatu keunggulan atau prestasi, memberikan suatu sumbangsi atau berhasil melaksanakan tugas yang diberikan sesuai target yang ditetapkan. Kepala sekolah SMP Negeri 2 Arungkeke dalam kutipan direktur jenderal guru dan tenaga kependidikan (GTK) Supriano mengatakan tujuan pemerintah selama lima tahun ke depan adalah meningkatkan kualitas sumber daya manusia (SDM), (Republika, 12-08-2019).

"SDM yang baik tentunya akan berhubungan dengan guru yang baik pula. SDM ini tidak luput dari peran guru, SDM yang unggul mendapatkan pelayanan pendidikan dan mempunyai kompetensi yang sesuai dengan kebutuhan."

Sejalan dengan pendapat direktur jenderal guru dan tenaga kependidikan di atas, makan kepemimpinan kepala sekolah di SMP Negeri 2 Arungkeke model kepemimpinan yang diharapkan mampu mengoptimalkan bahkan mendongkrak kinerja gurunya. Tujuan dari adanya penghargaan adalah untuk mendisiplinkan guru dalam melaksanakan tugasnya agar dalam melaksanakan pekerjaan yang diamanahkan dapat berjalan dengan baik serta memicu semangat kerja guru dalam mewujudkan tujuan dan visi misi sekolah.

f. f. Memberikan Insentif bagi Guru

Sertifikasi guru merupakan sebuah upaya pemerintah dalam rangka peningkatan mutu dan uji kompetensi tenaga pendidik dalam mekanisme teknis yang telah diatur oleh pemerintah melalui Dinas Pendidikan dan Kebudayaan (Dikbud) setempat yang bekerja sama dengan instansi pendidikan tinggi yang kompeten, kemudian diakhiri dengan pemberian sertifikat pendidik kepada guru yang telah dinyatakan memenuhi syarat standar profesional.

Adapun tujuan dari pemberian insentif kepada guru yaitu untuk meningkatkan kualitas kompetensi guru yang pada akhirnya diharapkan berdampak pada peningkatan mutu pendidikan serta dapat meningkatkan kesejahteraan guru secara finansial.

Mengenai kepemimpinan kepala sekolah dalam meningkatkan kinerja guru IPS di SMP Negeri 2 Arungkeke, berikut peneliti mendeskripsikan pembahasan terkait kepemimpinan yang diterapkan kepala sekolah menurut hasil penelitian di lokasi.

1. Kinerja Kepala Sekolah SMP Negeri 2 Arungkeke

Temuan peneliti terkait kinerja kepala sekolah dalam meningkatkan kinerja guru IPS memberikan arah bahwa kinerja kepala sekolah merupakan kemampuan untuk melaksanakan pekerjaan atau tugas yang dimiliki dalam menyelesaikan suatu pekerjaan di sekolah yang dipimpinnya. Kinerja kepala sekolah SMP Negeri 2 Arungkeke dalam rangka mempertahankan bahkan meningkatkan pemahaman dan pengetahuan guru atau dalam istilah meningkatkan kinerja gurunya sudah berjalan dengan sangat baik sesuai dengan visi dan misi sekolah, seperti penerapan kedisiplinan yang dijadikan sebagai contoh positif bagi guru, namun sarana dan prasarana sekolah perlu ditingkatkan karena terbatasnya alat teknologi seperti komputer dan print sehingga para guru kewalahan jika harus antri apabila akan menyelesaikan tugas administrasinya yang berhubungan dengan sekolah. Selain dari sarana dan prasarana pembayaran insentif bagi guru dan pegawai honorer berjalan sebagaimana juknis dan jumlah yang telah ditentukan. Kemudian pengelolaan dana 
operasional sekolah (BOS) lebih terorganisir dan transparan, kepemimpinan kepala sekolah yang diterapkan ini memicu meningkatnya jumlah siswa dari tahun 2019 hingga saat ini dan kesejahteraan guru pun terpenuhi.

2. Kinerja Guru IPS SMP Negeri 2 Arungkeke

Temuan peneliti pada kinerja guru IPS SMP Negeri 2 Arungkeke memberikan arah bahwa kinerja guru IPS merujuk pada pembuatan modul pembelajaran, seperti perencanaan program kegiatan pembelajaran, pelaksanaan kegiatan pembelajaran, dan tahap evaluasi.

3. Kepemimpinan Kepala Sekolah Dalam Meningkatkan Kinerja Guru IPS di SMP Negeri 2 Arungkeke. Berdasarkan temuan peneliti bahwa kepemimpinan kepala sekolah yang di terapkan untuk meningkatkan kinerja guru IPS di SMP Negeri 2 Arungkeke, yaitu Memberikan Motivasi Kerja Guru, Pembinaan Kedisiplinan, Memberikan Pelatihan Kinerja Guru, Memberikan Fasilitas, Pemberian Penghargaan, Memberikan Insentif Bagi Guru.

\section{Kesimpulan}

Kepemimpinan kepala sekolah yaitu proses pemahaman seorang guru dalam memberikan arti mengenai kepemimpinan yang dijalankan oleh kepala sekolah berdasarkan pengamatan, pengalaman, perhatian dan kepercayaan yang terseleksi selama menjadi guru. Kepemimpinan kepala sekolah dalam meningkatkan kinerja guru IPS di SMP Negeri 2 Arungkeke, kabupaten Jeneponto sesuai dengan hasil penelitian yang di lakukan peneliti di SMP Negeri 2 Arungeke dalam hal peningkatan kinerja guru IPS yaitu dengan memberikan motivasi semangat kerja guru, melakukan pembinaan disiplin, melakukan program kinerja guru, memberikan fasilitas belajar kepada guru IPS, memberikan penghargaan bagi guru yang berprestasi, memberikan insentif bagi guru.

\section{Referensi}

Ali, Mohammad. 1993. Strategi Penelitian Pendidikan.Cet. I; Bandung: Angkasa.

Aleweni, J. Thomas. Penilaian Kinerja dan Standar kinerja seri Manajemen Sumber Daya Manusia. Jakarta: Bhuana Ilmu Komputer, 2002.

Arikunto, Suharsimi.1006. Prosedur Penelitian; Suatu Pendekatan Praktik. Edisi Revisi VI,Cet.XIII; Jakarta: Rineka Cipta.

Danim, Sudarwan. 2010. Kepemimpinan Pendidikan kepemimpinan jenius (IQ+EQ), Etika,Perilaku, Motivasi, dan Mitos. Cet. I; Bandung: Alfabeta.

Darmadi, Hamid. 2009. Kemampuan Dasar Mangajar (landasan dan konsep implementasi). Cet. I; Bandung: Alfabeta.

Darma, Surya. 2005. Manajemen Kinerja, Falsafah, Teori dan Penerapannya. Cet. I;Yogyakarta: Pustaka Pelajar.

Fatah, Nanang. 2011. Landasan Manajemen Pendidikan. Cet. XI; Bandung: PT Remaja Rosdakarya.

Getteng, Abd. Rahman. 2011. Menuju Guru Profesionl dan Ber-Etika. Cet. III; Yogyakarta:Graha Guru.

Hsibuan, Malayu. S.P. 2005. Organisasi dan Motivasi. Cet V; Jakarta: Bumi Aksara, 2005.

Hadi, Sutrisno. 1990. Metodologi Research, Yokyakarta: Andi Offset.

Hamalik, Omar. 2000. Pengembangan Sumber Daya Manusia.Jakarta: Bumi Aksara.

Handoko,T. Hani. 2003. Manajemen. Ed. II. Cet.XVIII; Yogyakarta.

Hasbullah. 2001. Dasar-Dasar IImu Pendidikan,(Umum dan Agama Islam). Ed. I, Cet. II;Jakarta: Raja Grafindi Persada.

Mulyasa, E. 2009. Implementasi Kurikulum Tingkat Satuan Pendidikan Kemandirian Guru dan Madrasah .Cet. III; Jakarta: Bumi Aksara.

Mulyasa,E. 2011. Menjadi Kepala Sekolah Profesional.Cet.XI; Bandung: PT Remaja Rosdakarya.

Mulyasa,E. 2008. Menjadi Guru Profesional Menciptakan Pembelajaran Kreatif dan Menyenangkan.Cet. VII; Bandung:Remaja Rosdakarya. 
Marno \& Triyo Supriyatno. 2008. Manajemen dan Kepemimpinan Pendidikan Islam. Cet. I; Bandung: PT Refika Aditama

Mangkunegara, A.A Anwar Prabu. 2004. Manajemen Sumber Daya Manusia Perusahaan.Bandung: PT. Remaja Rosdakarya.

Moleong, Lexy. J. 2011 Metodologi Penelitian Kualitatif.Cet. XIX; Bandung: Remaja Rosdakarya.

Nawawi. 1995. Administrasi Pendidikan. Jakarta : Haji Masagung.

Rahman. Et., al. 2006. Peran Strategis Kepala Sekolah dalam Meningkatkan Mutu Pendidikan.Jatinangor: Alqaprint.

Rusman. 2009. Manajemen Kurikulum.Cet. I; Jakarta: Rajawali Pers.

Sagala, Syaiful. 2010. Manajemen Strategik dalam Peningkatan Mutu Pendidikan. Cet. IV;Bandung: Alfabeta Sagala,Syaiful. 2009. Kemampuan Profesional Guru dan Tenaga Kependidikan. Cet. I;Bandung: Alfabeta.

Sagala,Syaiful. 2010. Konsep dan Makna Pembelajaran untuk Membantu Memecahkan Problematika Belajar dan Mengajar. Cet. VIII;Bandung: Alfabeta.

Sastrowardoyo, Siswanto B. 202. Manajemen Sumber Daya Tenaga Kerja. Jakarta: Rineka Cipta.

Sutisna,Oteng. 1889. Administrasi Pendidikan. Ed. V. Cet. I; Bandung: Angkasa.

Santrock, John W. 2008. Psikologi Pendidikan. Edisi kedua, Cet. II; Jakarta: Kencana PrenadaMedia Group.

Sukmadinata, Nana Syaodih. 2009. Landasan Psikologi Proses Pendidikan. Cet. V; Bandung: PTRemaja Rosdakarya.

Sugiyono. 2008. Memahami Penelitian Kualitatif.Cet. IV; Bandung: Alfabeta.

Tilaar, H.A.R. 1999. Pengembangan Sumber Daya Manusia dalam Era Globalisasi. Jakarta:Ghia Indonesia.

Tim Dosen Administrasi Pendidikan Universitas Pendidikan Indonesia. 2009. ManajemenPendidikan. Bandung: Alfabeta.

Tafsir, Ahmad. 2010. Ilmu Pendidikan dalam Perspektif Islam.Cet. IX;Bandung: RemajaRosdakarya.

Tim Penyusun Kamus Bahasa Indonesia. 2005. Kamus Besar Bahasa Indonesia. Edisi III, Cet V; Jakarta Balai Pusaka.

Undang-undang RI Nomor 20 Tahun 2003 UU. 2011. Sistem Pendidikan Nasional. Cet.IV; Jakarta: Sinar Grafika.

Sagala,RI Nomor 20 Tahun 2003, UU. 2007. Sistem Pendidikan Nasional. Cet.IV; Jakarta: Sinar Grafika.

Undang-undang Guru dan Dosen. 2012. Cet III; Yoyakarta: Pustaka Pelajar.

Usman, Husaini. 2010. Manajemen: Teori, Praktik, dan Riset Pendidikan.Ed. III, Cet. II;Jakarta: Bumi Aksara.

Usman, Moh. User. 2011. Menjadi Guru Profesional. Cet.XXV; Bandung: Remaja Rosdakarya.

Uno, Hamzah B. 2008. Profesi Kependidikan, Problema, Solusi dan ReformasiPendidikan dilndonesia. Cet. III; Jakarta: Bina Aksara.

Wahjosumidjo. 2008. Kepemimpinan KepalaSekolah, Tinjauan Teoretik Dan Permasalahannya. Edisi I, Cet. IV; Jakarta: Rajawali Pers.

Wahyudi. 2009. Kepemimpinan kepala sekolah dalam organisasi pembelajar (LearningOrganization). Cet. II;Bandung: Alfabeta.

Wingo, Jiwo. B. 2003. Hartono,Tingkatan Kinerja Perusahaan Anda dengan Merit System. Jakarta: Raja Grafindo 